\title{
Adrenal histoplasmosis presenting as life-threatening adrenal insufficiency
}

\author{
Mragank Gaur, ${ }_{1}^{1}$ Jasmine Sethi, ${ }^{2}$ Saikat Mitra, ${ }^{1}$ Kirti Gupta (i) ${ }^{3}$
}

${ }^{1}$ Post Graduate Institute of Medical Education and Research, Chandigarh, India ${ }^{2}$ Nephrology, Post Graduate Institute of Medical Education and Research, Chandigarh, India ${ }^{3}$ Histopathology, Post Graduate Institute of Medical Education and Research, Chandigarh, India

\section{Correspondence to} Dr Jasmine Sethi; jasmine227021@gmail.com

Accepted 20 May 2021

\section{DESCRIPTION}

In endemic areas, histoplasmosis should always be considered as a differential diagnosis in a patient presenting with fever of unknown origin, chronic fatigue, adrenomegaly and hyperpigmentation. Early diagnosis and prompt institution of antifungal therapy is imperative to prevent mortality as significant majority of patients with adrenal histoplasmosis develop life-threatening adrenal insufficiency. ${ }^{1}$

A 57-year-old male security guard by occupation presented with 6-month history of fatigue, abdominal pain, dizziness on standing, low appetite and significant weight loss. His history was significant for type 2 diabetes mellitus for 8 years which appeared controlled with glycosylated haemoglobin of $7.1 \%$. Examination revealed body mass index of $18.2 \mathrm{~kg} / \mathrm{m}^{2}$. His supine blood pressure (BP) was $100 / 60 \mathrm{~mm} \mathrm{Hg}$ and his BP on standing erect was $70 / 50 \mathrm{mmHg}$, with development of presyncope. He had hyperpigmentation of tongue and buccal mucosa for approximately 4 months' duration (figure 1A). There was no palpable lymphadenopathy. Baseline laboratory parameters revealed serum sodium of $120 \mathrm{mmol} / \mathrm{L}(135-145 \mathrm{mmol} / \mathrm{L})$, potassium of $6 \mathrm{mmol} / \mathrm{L}(3.5-5.5 \mathrm{mmol} / \mathrm{L})$, random cortisol level of $93 \mathrm{nmol} / \mathrm{L}(133-537 \mathrm{nmol} / \mathrm{L})$ with an adrenocorticotropic hormone (ACTH) of $110 \mathrm{pg} /$ $\mathrm{mL}(7.2-63 \mathrm{pg} / \mathrm{mL})$, consistent with a diagnosis of primary adrenal insufficiency. ACTH stimulation test was not performed as hydrocortisone treatment had already been started. Contrast-enhanced CT of chest and abdomen showed bilateral symmetrical hypodense adrenal masses with smooth borders and preserved contour with no evidence of lymphadenopathy, hepatosplenomegaly or chest parenchymal abnormality (figure 1B). Our diagnostic considerations included infections such as tuberculosis and

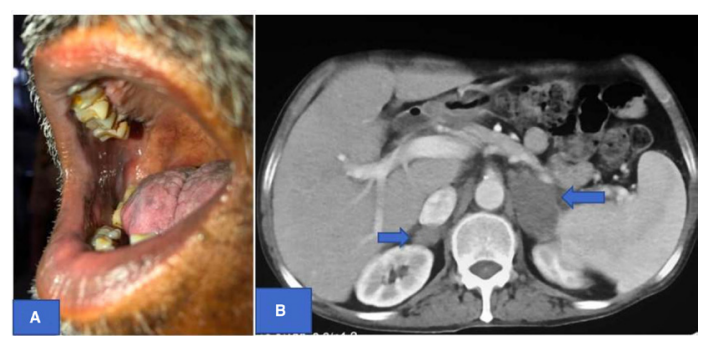

Limited 2021. No commercial re-use. See rights and permissions. Published by BMJ.

To cite: Gaur M, Sethi J,
Mitra S, et al. BMJ Case
Rep 2021;14:e243181.
doi:10.1136/bcr-2021-
243181

Figure 1 (A) Photograph showing tongue and buccal mucosal hyperpigmentation. (B) Contrast-enhanced $\mathrm{CT}$ of abdomen showing bilateral hypodense adrenal masses measuring $5 \times 3.8 \times 4.7 \mathrm{~cm}$ on the left side and $4.5 \times 2.4 \times 3.2 \mathrm{~cm}$ on the right side with smooth borders and preserved contour.

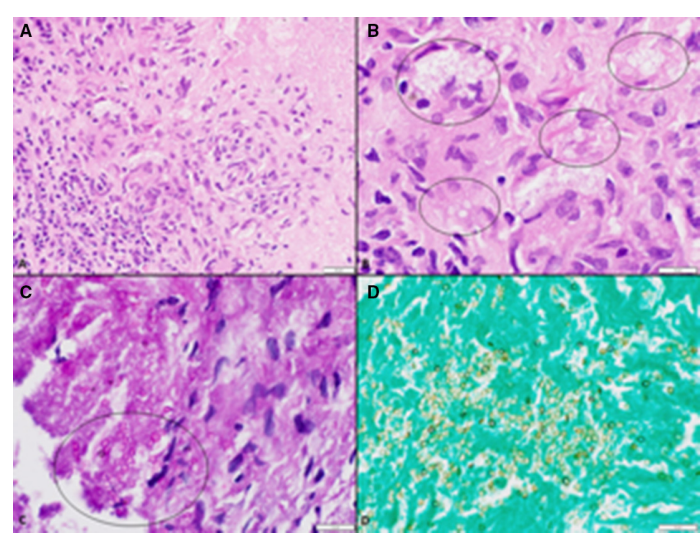

Figure 2 (A) High magnification depicting areas of necrosis bordered by epithelioid cells forming loose granuloma (H\&E, scale bar $20 \mu \mathrm{m}$ ). (B) Many intracellular and extracellular spores are seen as negative shadows under oil immersion (encircled) (H\&E, scale bar $10 \mu \mathrm{m})$. (C) Periodic acid-Schiff (PAS) stain highlights the fungal spores (encircled) (PAS, scale bar $10 \mu \mathrm{m}$ ). (D) Grocott's methenamine silver stain highlights the fungal spores (Grocott's, scale bar $10 \mu \mathrm{m}$ ).

histoplasmosis, metastasis from unknown primary, amyloidosis, lymphoma and neoplasia such as bilateral adrenocortical carcinoma. CT-guided biopsy from right adrenal mass revealed areas of necrosis with numerous fungal spores of Histoplasma highlighted by periodic acid-Schiff and Grocott's methenamine silver stain (figure 2A-D). Fungal culture confirmed growth of Histoplasma capsulatum.

Apart from diabetes mellitus, the patient had no other risk factor for histoplasmosis. Other immunodeficiency workup including HIV ELISA, dihydrorhodamine assay, Mantoux test, tissue GeneXpert for tuberculosis were negative. His CD4 count was 625 cells $/ \mathrm{mm}^{3}$, thus ruling out underlying immunodeficiency. A diagnosis of bilateral adrenal histoplasmosis causing primary adrenal insufficiency was made and the patient was initiated on physiological doses of glucocorticoid and mineralocorticoid. Antifungal therapy with oral itraconazole $200 \mathrm{mg}$ two times per day was started and is planned to continue for a duration of 1 year.

Histoplasmosis usually leads to self-limiting pulmonary infection that can rarely cause disseminated disease in immunosuppressed individuals. Although it can involve any organ system in disseminated disease, adrenal involvement is common and primary adrenal histoplasmosis has also been documented as in our case. The glucocorticoidrich adrenal cells and the relative scarcity of reticuloendothelial cells contribute to the tropism 
of Histoplasma for the adrenal gland. ${ }^{1}$ Common risk factors include immunosuppressed state such as diabetes, primary immunodeficiency, HIV infection, solid organ transplant recipients, extreme age and patients receiving immunosuppressive drugs. The differential diagnosis of bilateral adrenomegaly with Primary adrenal insufficiency (PAI) includes lymphomas, tuberculosis, fungal infections and metastatic cancer. ${ }^{2}$ The gold standard for diagnosis remains demonstration of fungal spores with background inflammatory response and isolation of fungus from tissue sample by fungal culture. ${ }^{3}$ In endemic region, histoplasmosis should always be contemplated as a possibility in a patient presenting with hypoattenuating bilateral adrenomegaly. For

\section{Learning points}

- Clinician should have high index of suspicion for adrenal histoplasmosis in a patient with primary adrenal insufficiency with adrenomegaly.

- Prompt institution of glucocorticoid and mineralocorticoid replacement therapy should be done once primary adrenal insufficiency is suspected.

- Adrenal histoplasmosis can present with life-threatening adrenal crisis. mild to moderate disease, itraconazole $200 \mathrm{mg}$ three times per day for 3 days followed by $200 \mathrm{mg}$ two times per day for 1 year is recommended. ${ }^{4}$ Remission rates of $80 \%-100 \%$ have been reported with itraconazole therapy. ${ }^{4}$

Contributors MG, JS: Manuscript writing, proofreading. SM, KG: Histopathological diagnosis and image acquisition.

Funding The authors have not declared a specific grant for this research from any funding agency in the public, commercial or not-for-profit sectors.

Competing interests None declared.

Patient consent for publication Obtained.

Provenance and peer review Not commissioned; externally peer reviewed.

\section{ORCID iD}

Kirti Gupta http://orcid.org/0000-0002-9999-3203

\section{REFERENCES}

1 Rog CJ, Rosen DG, Gannon FH. Bilateral adrenal histoplasmosis in an immunocompetent man from Texas. Med Mycol Case Rep 2016;14:4-7.

2 Mukherjee JJ, Villa ML, Tan L, et al. Bilateral adrenal masses due to histoplasmosis. J Clin Endocrinol Metab 2005;90:6725-6.

3 Rana C, Kumari N, Krishnani N. Adrenal histoplasmosis: a diagnosis on fine needle aspiration cytology. Diagn Cytopathol 2011;39:438-42.

4 Wheat LJ, Freifeld AG, Kleiman MB, et al. Clinical practice guidelines for the management of patients with histoplasmosis: 2007 update by the infectious diseases Society of America. Clin Infect Dis 2007;45:807-25.

Copyright 2021 BMJ Publishing Group. All rights reserved. For permission to reuse any of this content visit https://www.bmj.com/company/products-services/rights-and-licensing/permissions/

BMJ Case Report Fellows may re-use this article for personal use and teaching without any further permission.

Become a Fellow of BMJ Case Reports today and you can:

- Submit as many cases as you like

- Enjoy fast sympathetic peer review and rapid publication of accepted articles

- Access all the published articles

Re-use any of the published material for personal use and teaching without further permission

Customer Service

If you have any further queries about your subscription, please contact our customer services team on +44 (0) 2071111105 or via email at support@bmj.com.

Visit casereports.bmj.com for more articles like this and to become a Fellow 